\title{
Investigation of Polypyrrole-Based Iron Electrodes as Supercapacitors
}

\author{
Aziz Yă̆an \\ Chemistry Education, Dicle University, 21280, Diyarbakır, Turkey \\ E-mail: yagan@dicle.edu.tr
}

doi: $10.20964 / 2019.04 .12$

Received: 7 November 2018 / Accepted: 28 December 2018 / Published: 10 March 2019

\begin{abstract}
Polypyrrole (PPy) was successfully electropolymerized potentiodynamically on prepassivated Fe electrode in an aqueous solution containing monomer and oxalic acid. Electropolymerization of PPy was performed between $0.3 \mathrm{~V}$ and $0.8 \mathrm{~V}$ vs SCE with a scan rate of $20 \mathrm{mV} / \mathrm{s}$. Electrochemical properties of PPy coated Fe electrode were carried out using cyclic voltammetry, galvanostatic charge-discharge cycling and electrochemical impedance spectroscopy. The maximum specific capacitance of PPy coated Fe electrode is $2280 \mathrm{~F} / \mathrm{g}$. This indicates the feasibility of the PPy coated Fe electrode for use in electrochemical capacitor. However, the PPy coated Fe system behaved like PAni and not as Ppy, exhibited high capacitance.
\end{abstract}

Keywords: Supercapacitor; Polypyrrole; Iron electrode; Cyclic voltammetry

\section{FULL TEXT}

(C) 2019 The Authors. Published by ESG (www.electrochemsci.org). This article is an open access article distributed under the terms and conditions of the Creative Commons Attribution license (http://creativecommons.org/licenses/by/4.0/). 